\title{
KASVATUS\&AIKA $\mathbf{Y}$ \\ www.tsv, fi/tunnus
}

\section{ArtikKeli}

https://doi.org/10.33350/ka.82657

\section{Joukkoviestinnästä digiaikaan - Tieto- ja viestintätekniikka suomalaisen perusopetuksen opetussuunnitelmien perusteissa 1970-2014}

\begin{abstract}
Janne Säntti
Artikkelissa tarkastellaan suomalaisen peruskoulun ja perusopetuksen opetussuunnitelman perusteiden tieto- ja viestintätekniikkaan liittyviä merkityksiä ja niiden muuttumista viidellä eri vuosikymmenellä. Opetussuunitelmien perusteet heijastelevat muuttunutta suomalaista yhteiskuntaa, jossa myös tieto- ja viestintätekniikan merkitys on muuttunut. Kaikkia tutkittuja opetussuunnitelmia yhdistää tieto- ja viestintäteknisen todellisuuden myöntäminen, ja tieto- ja viestintätekniikan merkitys vain kasvaa tultaessa kohti nykyaikaa. Lisäksi opetussuunnitelmissa korostuu tietoja viestintätekniikkaan liittyvä aktiivinen, kriittinen suhtautuminen sekä sen merkitysten pohtiminen.
\end{abstract}

\section{Tieto- ja viestintätekniikkaan liittyvät odotukset}

Peruskoulun kehittäminen asettaa varsin suuria odotuksia tieto- ja viestintätekniikalle, joka nähdään yhtenä mahdollisuutena korostaa tasa-arvoa, yksilöllisyyttä ja oppilaiden välistä yhteistyötä. Tieto- ja viestintätekniikan sanotaan tarjoavan myös uudenlaista ymmärrystä tukevaa, positiivista, motivoivaa ja kannustavaa sekä suvaitsevaista ja joustavaa oppimista vastapainoksi painetulle tekstille ja liikkumattomalle kuvalle, joiden sanotaan edustavan passiivista vastaanottamista. (Harinen ym. 2015, 71-72; Liikenne- ja viestintäministeriö 2010, 7-9.)

Tieto- ja viestintätekniikka haastaa myös koulun fyysiset puitteet. Perinteiset koulurakennukset ovat menettämässä merkitystään oppimisen paikkoina tietoverkkojen mahdollistaessa aivan uudenlaisia ajasta ja paikasta riippumattomia oppimisympäristöjä (Jordman ym. 2015, 83; Liikenne- ja viestintäministeriö 2010, 7-10; Sitra 2015, 8, 12). Koulun fyysisten elementtien, rakenteiden ja toimintakulttuurin lisäksi tieto- ja viestintätekniikka haastaa koulun toimijat. Visioissa vastakkain asettuvat usein konservatiiviset opettajat uudistu- 
mismielisten kollegoiden käyttäessä viimeisintä opetusteknologiaa ja luopuessa pulpettipakosta (Lonka ym. 2013, 94-95; Sitra 2015, 7). Oppilaat sen sijaan, kutsuttiinpa heitä sitten läppärisukupolveksi tai diginatiiveiksi, esitellään passiivisen opetuskulttuurin uhreiksi, joiden pelastamisen viimeinen hetki on käsillä (Ouakrim-Soivio 2010, 40-43).

Edellä mainitut tieto- ja viestintätekniikkaan liittyvät odotukset paikantuvat koulumaailmaan. Tämän lisäksi tieto- ja viestintätekniikan sanotaan liittyvän keskeisesti Suomen kilpailukyvyn vahvistamiseen ja hyvinvoinnin säilyttämiseen (Liikenne- ja viestintäministeriö 2010, 8-9). Yhtenä 21. vuosisadan taidoista mainitaan valmius nivoa teknologiaa luontevaksi osaksi oppimista. Jos koulu halutaan tuoda tälle vuosituhannelle, teknologian roolin ja virtuaalisuuden tulee olla oppimisen arjessa itsestäänselvyys. Opettajajohtoiseen ja oppiainejakoiseen kouluun ei tätä teknologiaa kannata kuitenkaan tuoda, vaan koko pedagoginen toimintamalli täytyy ajatella aivan uudestaan (Elinkeinoelämän keskusliitto 2011, 27; Jordman ym. 2015, 80; Kumpulainen \& Lipponen 2010, 12-13).

Edellä on esitelty muun muassa elinkeinoelämän ja ammattiyhdistysten edustajien, hallinnon virkamiesten, opettajien, yliopistotutkijoiden sekä poliittisten toimijoiden näkemyksiä koulusta ja sen opetussuunnitelmatarpeista. Nämä asiantuntijapuheenvuorot liittyvät osaksi ajankohtaista medioissa käytävää keskustelua tieto- ja viestintätekniikasta. Ne ovat esimerkinomaisia näkemyksiä koulusta ja sille toivotusta kehityssuunnasta viimeisen kymmenen vuoden ajalta. Ne edustavat yhtä, mutta hyvin laajalle levinnyttä tapaa puhua tietoja viestintätekniikan potentiaalista muuttaa maailmaa, ja tässä tapauksessa siis erityisesti koulua, paremmaksi paikaksi. Kyse on maailmanlaajuisesta trendistä (Cuban 2001; Nivala 2009; Player-Koro 2016; Saari \& Säntti 2018; Unwin 2015).

Cubanin $(2001,1)$ mukaan samat äänet, jotka tuomitsevat vallitsevan koulun totaalisen epäonnistuneeksi, toisaalta luottavat koulun loputtomaan kykyyn rakentaa parempaa yhteiskuntaa - kunhan koulu vain on viritetty ajan vaatimuksiin sopivaksi. Tieto- ja viestintätekniikalla nähdään tässä uudistuksessa usein keskeinen rooli. Kiinnostukseni lähteä tutkimaan tieto- ja viestintätekniikan merkitystä suomalaisessa peruskoulussa kumpuaa juuri edellä mainitun kaltaisista puheenvuoroista. Vaikka niissä viitataan suhteellisen harvoin tarkastelun kohteena oleviin opetussuunnitelmiin, voi näkemyksiä kuvailla ihanteellisen opetussuunnitelman elementeiksi (Klein ym. 1979, ks. myös McNeil 1985, 87-88; Vitikka 2009, 51).

Tarkastelen seuraavassa miten tieto- ja viestintätekniikkaa ja sen merkitystä on esitetty suomalaisen peruskoulun tai perusopetuksen viidessä eri opetussuunnitelmassa ajanjaksolla 1970-2014. Tutkimus on syntynyt tarpeesta tarkentaa kuvaa tieto- ja viestintätekniikan merkityksestä suomalaisessa peruskoulutuksessa. Sotienjälkeisen suomalaisen yhteiskunnan modernisaatioprosessi kiteytyy osin juuri peruskoulussa. Siksi opetussuunnitelmien teknologiamainintojen voi olettaa osaltaan heijastelevan koululle asetettuja muutosvaatimuksia. Viiden eri aikakauden opetussuunnitelman vertailu mahdollistaa myös tieto- ja viestintätekniikkaan liittyvien merkitysten mahdollisen muuttumisen tarkastelun. Oletettavaa on, että peruskoulun ensimmäisen opetussuunnitelman perusteet poikkeavat tieto- ja viestintäteknisiltä oletuksiltaan merkittävästi nykyisestä opetussuunnitelmasta. Vallitsevassa opetussuunnitelmassa tieto- ja viestintätekniikka tavataan mainita aivan keskeisenä megatrendinä 21. vuosisadan taitojen ja oppimisen kaikkiallisuuden ohella ja niihin elimellisesti kytkeytyneenä (Vahtivuori-Hänninen ym. 2014). 


\section{Tieto- ja viestintätekniikka koulutuksessa}

Cuban (2001, 12-15) esittää kolme syytä siihen, miksi uuden opetusteknologian on haluttu korvaavan oppikirjan ja liitutaulun kaltaiset perinteiset opiskeluvälineet. Ensinnäkin koulusta on haluttu tehdä aiempaa tehokkaampi ja tuottavampi. Tarkoituksena ei ole ollut välttämättä opettajien korvaaminen vaan heidän työnsä tehostaminen. Tieto- ja viestintätekniikan merkittävän roolin muilla yhteiskunnan sektoreilla oletetaan toimivan koululle kannustavana ja toisaalta velvoittavana esimerkkinä. Toiseksi Cubanin mukaan on haluttu muuttaa opettamista ja oppimista aktiivisemmaksi ja paremmin koulun ulkopuolista todellisuutta kuvastavaksi. Taustalla vaikuttaa näkemys siitä, että koulu on muusta yhteiskunnasta erillinen saareke, joka on tieto- ja viestintätekniikaltaan jäljessä yhteiskunnan muita sektoreita (Saari \& Säntti 2018). Kolmas peruste löytyy työ- ja elinkeinoelämästä: tieto- ja viestintätekniikan oletetaan vievän nykyoppilaat suoraan vallitsevaan tai mahdollisesti jopa tulevaisuuden työelämään.

Cubanin argumentit linkittyvät selkeästi ympäröivän yhteiskunnan tarpeisiin. Taloudelliset argumentit, tulevaisuuden työelämä ja erityisesti tieto- ja viestintätekniikka-alojen tarpeet tavataan yleensä mainita pohdittaessa tieto- ja viestintätekniikan merkitystä koulussa ja opetussuunnitelmissa. Työelämän lisäksi yhteiskunnallinen osallistuminen ja kansalaisuuteen liittyvät seikat sekä vapaa-aika näyttäisivät edellyttävän perusopetukselta tieto- ja viestintäteknisten taitojen huomioimista. Näiden taitojen perustellaan olevan niin merkittävä osa nykyelämää, että ne yksinkertaisesti kuuluvat kaikille. (Hawkridge 1990; Hoikkala \& Kiilakoski 2018; Passey 2017; Unesco 2012.)

Hoikkala ja Kiilakoski $(2018,23-30)$ mainitsevat ihmissuhteet ja erityisesti hyvän elämän digitalisaatioon liittyvänä kysymyksenä, joskin hyvän elämän tavoittelua kaikessa laajuudessaan voi pitää yhtenä keskeisenä kasvatuksen päämääränä. Perusteet kumpuavat myös oppijoista ja heille luontaisista taipumuksista tai taidoista, joihin tieto- ja viestintätekniikan sanotaan sopivan. Tämä oppijanäkökulma (Passey 2017) on jossain määrin ongelmallinen, koska silloin tavataan mainita diginatiivit. Heidän olemassaolonsa yhtenäisenä ryhmänä on kyseenalaistettu toistuvasti (ks. esim. Kirschner \& Merriënboer 2013; Selwyn 2009). Yhteiskunnallisten ja ihmisyyteen liittyvien tarpeiden lisäksi katsotaan, että tieto- ja viestintätekniikan avulla kyetään jalostamaan keskeisiä nyky-yhteiskunnassa tarvittavia taitoja kuten ongelmanratkaisua, luovuutta ja loogista päättelyä (Passey 2017).

Koottaessa yhteen edellä mainittuja perusteluita tieto- ja viestintätekniikan merkityksestä koulutuksessa voidaan havaita, kuinka syitä tieto- ja viestintätekniikan käyttöön löytyy niin tulevaisuuden yhteiskunnasta, koulun ja työelämän kehittämistarpeista, oppijoiden luontaisista taipumuksista kuin yleisemminkin digitaalisen elämänmenon kaikkiallisuudesta ja halusta parempaan elämään. Syyt ovat siten koulun sisäisiä ja ulkoisia sekä viime kädessä inhimillisen potentiaalin toteutumiseen liittyviä.

Esitettyjen tarpeiden ja syiden taustalla vaikuttaa erilaisia tapoja suhtautua tieto- ja viestintätekniikkaan. Teknologinen determinismi merkitsee näkemystä, jonka mukaan teknologialla on todellista kykyä muuttaa yhteiskuntaa, ihmistä ja uudistaa työelämän tarvitsemia kompetensseja. Yksinkertaisimmillaan on kyse siitä, että tieto- ja viestintätekniset laitteet saavat sellaisenaan aikaan muutosta, joka nähdään ensisijaisesti positiivisena kehityksenä tai jopa välttämättömyytenä. Näkökulmaa kritisoidaan siitä, että käyttäjille jää helposti pas siivinen teknologian vastaanottajan rooli. Mahdollinen tieto- ja viestintätekniikkaan liittyvä vastarinta saatetaan tukahduttaa viittaamalla vastaanottajien negatiivisiin ja ajastaan jälkeen jääneisiin asenteisiin tai riittämättömään tieto- ja viestintätekniseen osaamiseen. (Nivala 2009; Oliver 2011; Pirhonen \& Häkkinen 2014; Player-Koro 2016; Saari \& Säntti 2018.) 
Suomalaisen koulutuksen teknologianäkemyksiä on arvosteltu teknologista determinismiä myötäilevästä kritiikittömyydestä (ks. esim. Pirhonen \& Häkkinen 2014 ja Saari \& Säntti 2018). Myös Mertalan (2019) mukaan tällä hetkellä hallitsevaksi kertomukseksi nousee teknologiaoptimismi, jollaista edustavat myös johdannossa esitellyt myönteiset käsitykset tasa-arvon ja osallisuuden toteutumisesta tieto- ja viestintäteknisen kehityksen vanavedessä. Tämä hegemoninen diskurssi näyttää puolestaan tarvitsevan vastinpinnan, jollaiseksi muodostuu kertomus menneisyyteen juuttuneesta koulusta (Saari \& Säntti 2018).

Positiivisen determinismin vastinpariksi asettuu kielteisiä teknologiakäsityksiä heijasteleva teknopessimismi, jolloin korostuvat tieto- ja viestintätekniikkaan liittyvät negatiiviset merkitykset. Tällöin tieto- ja viestintätekniikka esitellään pikemminkin ihmistä orjuuttavana kuin vapauttavana elementtinä. Näkökulmaan saattaa liittyä halu suojella etenkin yhteiskunnan nuorimpia jäseniä tieto- ja viestintätekniikan liialliselta käytöltä. Lisäksi saatetaan korostaa tieto- ja viestintätekniikan tuottamaa epätasa-arvoa sekä viestinnän yksipuolisuutta synnyttäviä ja mahdollistavia mekanismeja. (Airaksinen 2003, 23-29; Friesen 2008; Mertala 2019; Selwyn 2011.)

Kahden esitellyn ääripään lisäksi on olemassa vaihtoehto, jonka mukaan teknologia, siis myös tieto- ja viestintätekniikka, rakentuu sosiaalisissa tilanteissa ja on ihmisten aktiivisen toiminnan tulosta. Tieto- ja viestintätekniikan käyttäjät ovat siis aktiivisia toimijoita, jotka vaikuttavat toiminnallaan tieto- ja viestintätekniikan käyttöön ja merkityksiin. Siten tietoja viestintätekniikka voi olla myönteistä tai kielteistä, mutta se ei ole lähtökohtaisesti jompaakumpaa. Osin tämä lähtökohta palautuu teknologiaan liittyvien kertomusten ja vastakertomusten vastaanottoon, osin myös tuottamiseen, mutta ehdottomasti niiden välisen ristiriitaisuuden tunnustamiseen. Olennaista on huomata, kuinka teknologiapuheeseen kytkeytyy erilaisia päämääriä ja intressejä. (Mertala 2019; Oliver 2011; Selwyn 2010; Selwyn 2016.)

\section{Opetussuunnitelmat oman aikansa peileinä}

Opetussuunnitelmat heijastelevat aikansa arvostuksia ja toiveita, joita vallassa olevat sukupolvet haluavat välittää seuraaville sukupolville. Opetussuunnitelmien ymmärtäminen ilman kontekstia ja kulloisiakin sosiaalisia, taloudellisia ja poliittisia virtauksia lienee täysin mahdotonta. Tutkimuksen kohteena olevalla tieto- ja viestintätekniikalla puolestaan on erittäin vahvat yhteydet poliittisiin ja taloudellisiin intresseihin (Selwyn 2016). Toisaalta taas suomalaisessa peruskoulukeskustelussa tasa-arvon merkitys on ollut keskeinen, mikä on luonnollisesti heijastunut opetussuunnitelmiin (ks. esim. Ahonen 2004). Opetussuunnitelma voi olla myös yhteiskunnallisen epätasa-arvon oikeuttaja, jatkaja tai jopa edistäjä. Näiden jakolinjojen tunnistaminen kuvaakin hyvin opetussuunnitelmatutkimuksen historiaa (Pinar 1995, 243-259, 847-848; Rokka 2011).

Tutkimuskohteenani ovat lopulliset opetussuunnitelmatekstit, jotka ovat valmistuneet kansallisessa opetussuunnitelmien laatimisjärjestelmässä. Vaikka jokainen teksti on ainutlaatuinen ja oman aikakautensa tuote, yhdistää niitä kuitenkin suomalainen opetussuunnitelmatraditio (Rokka 2011, 16). Haluan korostaa, että en ole tutkinut opetussuunnitelmien rakentumista ja tuossa laatimisvaiheessa vaikuttaneita mahdollisia taustaryhmiä erilaisine intresseineen. Keskityn siis viiteen eri aikana tuotettuun suunnitelmaan opetuksen ja oppimisen järjestämisestä suomalaisessa peruskoulutuksessa. Samoin vaikenen opetussuunnitelmien toteutumisesta ja siitä, miten ne on koettu esimerkiksi opettajien ja oppilaiden kes kuudessa.

Peruskoulukauden opetussuunnitelmien perusteet ovat näkökulmasta riippuen hyvin samankaltaisia tai sitten kovin erilaisia. Eroa on ensinnäkin ohjeistuksen tarkkuudessa ja 
osin myös sitovuudessa. Opetussuunnitelmien laajuudessa ääripäihin asettuvat vuoden 1970 opetussuunnitelman perusteet ja ainekohtainen osuus (Opetusministeriö 1970a, Opetusministeriö 1970b) kahden osan 700 sivullaan siinä missä vuoden 1994 opetussuunnitelman perusteet (Opetushallitus 1994) mahtuvat runsaaseen sataan sivuun. Yhtäläisyyttä luo se seikka, että kaikki viisi opetussuunnitelmadokumenttia rakentuvat alun yleisiä osuuksia lukuun ottamatta eri tieteenaloihin perustuvista oppiaineista (Marsh 2009, 5-6; Schiro 2013).

Oppiainejakoisuuteen on pyritty tuomaan horisontaalisuutta läpäisyperiaatteella, opetuksen eheyttämisellä ja viimeisimmässä dokumentissa laaja-alaisilla kompetenssipohjaisilla osaamisalueilla. Oppiainejakoisuuden ja integroivien elementtien välinen vuoropuhelu kuvaa hyvin suomalaisen opetussuunnitelman historiaa, mistä vuoden 1970 peruskoulun opetussuunnitelmadokumentin (Opetusministeriö 1970a, Opetusministeriö 1970b) kahtiajakoisuus, osin jopa ristiriitaisuus, on oiva esimerkki. Viime kädessä kysymys lienee siitä, tuleeko opetussuunnitelman rakentua oppiaineiden pohjalle vai oppilaiden oppimistarpeisiin perustuen ja miten yhteiskunnan odotukset tehokkuudesta tai yhteiskunnallisesta aktiivisuudesta näkyvät. Kyse on myös siitä, halutaanko opetussuunnitelmalla edistää jatkuvuutta ja tradition välittymistä vai vallitsevien olosuhteiden muuttamista. (Lahdes 1980, 112-113; Marsh 2009, 10; McNeil 1985; Pinar 1995, 686; Salminen 2002, 23; Schiro 2013; Vitikka 2009, 23, 56-70.)

Kuhunkin opetussuunnitelmaan on kietoutunut laatijasukupolvien näkemys tieto- ja viestintätekniikasta ja sen merkityksestä keskeisessä peruskoulutusta ohjaavassa asiakirjassa. Vaikka opetussuunnitelma hallinnollisena ja byrokraattisena asiakirjana ikään kuin lukitsee oppisisällöt, haastaa se samalla keskustelemaan sisällöllisistä painotuksista, sanavalinnoista ja käsiteltyjen sisältöjen tarpeellisuudesta tai välttämättömyydestä. Kyse on siis myös siitä, kuinka annetuiksi nämä sisällöt ja lähestymistavat ymmärretään. (Pinar 1995, 847-849; Vitikka 2009, 49-50; Young \& Muller 2010.)

\section{Opetussuunnitelmien analysointi ja tutkimuksen metodologiset ratkaisut}

Tutkimuksen menetelmällisenä ratkaisuna päädyin käyttämään laadullista sisällönanalyysiä (Tuomi \& Sarajärvi 2018). Aineistosta voi ensinnäkin tehdä havaintoja tieto- ja viestintäteknisten ilmaisujen määrästä. Määrän perusteella ei kuitenkaan voi tehdä kovin pitkälle meneviä oletuksia tieto- ja viestintätekniikan merkityksestä kullakin opetussuunnitelmakaudella. Havaintojen määrä oli tutkimuksessa siten viitteellinen ja pikemminkin apuväline kuin analyysin lähtökohta tai varsinainen tutkimustulos (Salo 2015). Ennen varsinaista analyysiä oli kuitenkin otettava kantaa siihen, miten tieto- ja viestintätekniikka on nimetty ja miten se ilmenee tarkastelun kohteena olevissa opetussuunnitelmissa.

Peruskoulun ensimmäisen opetussuunnitelman aikana teknologista kehitystä edustivat televisio, kielistudiot ja piirtoheittimet, kun taas 2000-luvulla puhutaan henkilökohtaisista ja taskuun mahtuvista mobiililaitteista sekä digitaalisista oppimisympäristöistä. Puolen vuosisadan aikana opetussuunnitelmien perusteissa on puhuttu opetusteknologiasta, ATKs ta, tieto- ja viestintäteknologiasta, tieto- ja viestintätekniikasta ja viimeiseksi digitalisaatiosta. Käytän tässä tutkimuksessa termiä tieto- ja viestintätekniikka. Joskus synonyymisestikin käytetty tieto- ja viestintäteknologia viittaa ensisijaisesti tekniikan teoriaan ja oppiin, ei käytännön sovelluksiin, jotka ovat nimenomaan tämän tutkimuksen ytimessä (Meisalo, Sutinen \& Tarhio 2003). Myös Opetushallitus ja Opetus- ja kulttuuriministeriö käyttävät ensisijaisesti termiä tieto- ja viestintätekniikka. Käytän myös lyhennettä TVT, minkä voidaan tulkita viittaavan niin tekniikkaan kuin teknologiaan. 
Suomenkielinen termi tieto- ja viestintätekniikka kuvaa englanninkielisen vastineensa ICT:n (information and communication technology) tavoin tietotekniikan ja viestintätekniikan yhteenkietoutumista: teknisesti syntynyt tieto on tarkoitettu myös viestittäväksi (Cantoni \& Danowski 2015; Korhonen 2017; Meisalo, Sutinen \& Tarhio 2003, 29). Verkon siirtonopeuksien kasvun ja tietokoneiden lisääntyneen suorituskyvyn myötä on syntynyt aivan uusi digitaalisten palvelujen maailma. Pohjimmiltaan kyse on kuitenkin ideoiden leviämisen mahdollistamasta teknisestä kehityksestä aivan kuten kirjapainotaidon ja radionkin kohdalla. Tieto- ja viestintätekniikassa on siis ensisijaisesti kyse teknologiasta, joka takaa pääsyn informaation luo, mutta joka mahdollistaa myös informaation käsittelemisen ja välittämisen. Näiden teknologisten artefaktien ja toimintojen lisäksi modernimpi näkemys sisältää myös ohjelmistot ja tietoverkot unohtamatta teknologian käyttöä sääteleviä lakeja, asetuksia ja traditioita. (Unwin 2015.)

Perehtyessäni peruskoulun opetussuunnitelmiin etsin tieto- ja viestintäteknisiä ilmauksia. Suljin analyysini ulkopuolelle oppikirjat, jotka edelleen edustavat ensisijaisesti koulun tarpeisiin tehtyä oppimateriaalia. Toiseksi Koulu-TV ja digitaaliset oppikirjat ovat kyllä esimerkkejä tieto- ja viestintätekniikan alaan kuuluvista oppimateriaaleista, mutta paperis ten oppikirjojen tavoin ne on tehty erityisesti pedagogisiin tarkoituksiin ja ovat siten rinnastettavissa oppikirjoihin. Koska tarkastelen tieto- ja viestintätekniikkaa, ovat tutkimukseni kohteet usein sähköisiä. Silti hyväksyin analyysini kohteeksi myös sanomalehden, jonka rooli korostui etenkin peruskoulun alkuvaiheessa joukkotiedotuksesta puhuttaessa (Meisalo, Sutinen \& Tarhio 2003).

Tarkastelemaani tieto- ja viestintätekniikkaa kuvaa ensisijaisesti se, että kyse on opetukseen soveltuvista välineistä ja sisällöistä, joita ei ole kuitenkaan ensisijaisesti tehty pedagogiseen tarkoitukseen (vrt. oppikirjat). Siten en päätynyt käyttämään tutkimuskohteestani käsitettä opetusteknologia, koska se tarkoittaa erityisesti pedagogisiin tarpeisiin tehtyä tieto- ja viestintätekniikkaa (Meisalo, Sutinen \& Tarhio 2003, 24). Seuraavassa on luettelo keskeisistä ilmaisuista jaettuna kolmeen pääryhmään. Kyseiset ilmaisut esiintyvät peruskoulun opetussuunnitelmissa kuvaamassa rajaamaani tieto- ja viestintätekniikkaa:

Viestintään liittyvät, sisältöpainotteiset:

Joukkotiedotus, TV, radio, sanomalehdet, digitaaliset materiaalit, sähköiset lähteet, media, uusi media, sosiaalinen media, Internet

Tietotekniset, välinepainotteiset:

opetuskoneet, piirtoheitin, episkooppi, levysoitin, AV-välineet, nauhoituslaitteet, tietokone, tietokoneohjelmat, ohjelmistot, ATK, mobiililaitteet

Kokoavat, kulttuuriset käsitteet:

Tieto-ja viestintätekniikka, teknologia, uusi teknologia, opetusteknologia, tekniikka, tietoyhteiskunta, monimediaisuus, digitaalisuus, monilukutaito, joukkotiedotuskasvatus, tietoverkot, mediatekniikka

Aineiston perusteella tekemäni jako ei ole yksiselitteinen. Ensinnäkin kyseiset kategoriat ja niihin kuuluvat viestinnälliset ja tekniset ilmaisut eivät ole toisiaan poissulkevia. Siten esimerkiksi kolmas ryhmä sisältää nimensä mukaisesti viestinnällisiä sekä tietoteknisiä välineitä ja sisältöjä (Meisalo, Sutinen \& Tarhio 2003).

Ensimmäisenä tutkimuksen vaiheena oli etsiä kaikki mahdolliset viidessä opetussuunnitelmassa esiintyvät tieto- ja viestintätekniset nimekkeet, joista jokainen asettuu johonkin 
kolmesta edellä mainitusta pääluokasta. Kyse on varsin kattavasta terminologia-avaruudesta ja toisaalta hyvin tulkinnanvaraisesti rajautuvasta analyysikohteesta.

Rajattuani tutkimuskohteen aloin etsiä aineistosta erilaisia kohteeseen liittyviä merkityksiä, jäsennyksiä ja kirjoittamisen tapoja tuottaakseni uudenlaista aiheeseen liittyvää ymmärrystä (Ruusuvuori, Nikander \& Hyvärinen 2010). Sisällönanalyysi jaetaan usein aineisto- ja teorialähtöiseen lähestymistapaan. Aineistolähtöisen sisällönanalyysin mahdollisena ongelmalähteenä on toisaalta aineiston autenttisuuden ylikorostuminen ja toisaalta tutkijan esioletusten riittämätön tarkastelu. (Ruusuvuori, Nikander \& Hyvärinen 2010; Salo 2015.) Teorialähtöisyys puolestaan asettaa, riippuen siitä miten teoria ymmärretään, varsin haastavan lähtökohdan monelle sisällönanalyysille ja edellyttää aineiston keräämisen, analysoinnin ja tulkinnan taustalle tiukasti rajattua eksplisiittistä teoriaa (Salo 2015).

Analyysissäni olen tukeutunut kolmeen edellä mainittuun tapaan suhtautua tieto- ja viestintätekniikkaan: positiivinen deterministinen, negatiivinen deterministinen ja toimijuutta korostava. Ne toimivat analyysini taustalla eräänlaisina puheavaruuksien tiivistyminä ja tutkimuksellisina etukäteisoletuksina. Vaikka näitä kolmea lähestymistapaa ei voi pitää teorioina sanan varsinaisessa merkityksessä, antanevat ne kuitenkin mahdollisuuden ajatella ja "teoretisoida aineiston kanssa" (Salo 2015).

Ensimmäisenä tutkimustehtävänä tarkastelen, miten tieto- ja viestintätekniikkaa ja sen merkitystä on esitetty suomalaisen peruskoulun tai perusopetuksen viidessä eri opetussuunnitelmassa ajanjaksolla 1970-2014. Olen kiinnittänyt huomiota siihen, onko tieto-ja vies tintätekniikka mainittu mahdollisesti välttämättömyytenä tai korostettu sen hyödyllisyyttä tai haitallisuutta. Samoin olen kiinnittänyt huomiota siihen, miten toimijuutta, olipa kyse sitten oppilaista, opettajista tai koko koululaitoksesta, on määritelty suhteessa TVT:hen. Lisäksi olen kiinnostunut siitä, kenen tai keiden näkökulmista tieto- ja viestintätekniikkaa on tarkasteltu.

Toinen tutkimuskysymys pohjautuu ensimmäiseen: tarkastelen onko TVT:hen kohdistuva puhetapa mahdollisesti muuttunut näiden viiden eri opetussuunnitelman välillä. Tieto- ja viestintäteknisiin kannanottoihin vaikuttaa luonnollisesti niiden esittämisaika. Siksi kukin opetussuunnitelma on asetettava osaksi kirjoitushetkensä yhteiskunnallista tilannetta, opetussuunnitelma-ajattelua ja näkemystä TVT:n merkityksestä. Päädyin esittelemään ensin opetussuunnitelmat kronologisessa järjestyksessä. Vaihtoehtoista mutta tässä yhteydessä pikemminkin täydentäväksi miellettävää temaattista tarkastelua esittelen kokoavassa osiossa. Kun kukin opetussuunnitelma on esitelty ensin suhteessa omaan aikaansa, voi vasta tämän jälkeen esittää näkemyksiä teemojen mahdollisesta toistumisesta, muuttumisesta tai murtumisesta edettäessä vuosikymmeneltä toiselle ja pohdittaessa mahdollisia syitä tapahtuneeseen.

\section{Peruskoulun opetussuunnitelmakomitean mietintö 1970: osa I Opetussuunnitelman perusteet ja osa II Oppiaineiden opetussuunnitelmat}

Peruskoulun ensimmäiset vuodet ajoittuvat Alasuutarin (1996) mukaisesti vaiheeseen, jossa siirryttiin vähitellen sotienjälkeisestä moraalitaloudesta suunnittelutalouteen. Rinnakkaiskoulu edusti vanhaa maatalousvaltaista Suomea, kun taas uusi peruskoulun myötäili suunnitteluideologian mukaista lähiyhteisön korvaavaa ja tasa-arvon merkitystä korostavaa koulutusjärjestelmää. Rinteen $(1984,135)$ näkemyksen mukaan opetussuunnitelma ja koulutus yhteiskunnallistuivat demokratiavaatimusten vanavedessä.

Ensimmäinen peruskouluun liittyvä opetussuunnitelmadokumentti on kaksiosainen. Ensin on niin sanottu yleinen osa eli Peruskoulun opetussuunnitelmakomitean mietintö I: 
Opetussuunnitelman perusteet (Opetusministeriö 1970a), jossa keskitytään peruskoulun yleisiin tavoitteisiin (Opetusministeriö 1970a, 56). Toisessa osassa Peruskoulun opetussuunnitelmakomitean mietintö II: Oppiaineiden opetussuunnitelmat (Opetusministeriö 1970b) käsitellään puolestaan varsinaisia oppiaineita. Toisen osan sanotaan sisältävän paljon keskikoulun oppisisältöjä niiden siirryttyä lähes sellaisenaan peruskouluun, mitä ensimmäisessä osassa myös kritisoidaan (Lappalainen 1985, 234; Opetusministeriö 1970a, 66).

Vuoden 1970 opetussuunnitelman ensimmäinen osa eli perusteet on suhteellisen teknologiapainotteinen. Alkusivuilla mainitaan tekniset laitteet, "jotka auttavat ihmistä tallentamaan tietoa teoriassa miltei rajattomasti” (Opetusministeriö 1970a, 27). Myös tietojen automaattinen käsittely mainitaan ja todetaan, kuinka "koko maapallon kattava tietoliikenne tehostuu" (Opetusministeriö 1970a, 34, 233). Näissä maininnoissa näyttäisi olevan kuitenkin enemmän kyse tulevaisuuspohdinnasta kyberneettisine oletuksineen ja informaation takaisinkytkentöineen kuin vallitsevasta yhteiskunnallisesta tilanteesta saati koulutodellisuudesta. Vaikka opetussuunnitelmassa esitetään huomioita tulevaisuudesta ja se nähdään jo tässä vaiheessa varsin teknologisena, pohditaan myös tulevaisuuden avoimuutta: "ettei ole kovinkaan suurta yksimielisyyttä siitä yhteiskunnasta, johon meidän tulisi pyrkiä, tai jollainen meillä tulee olemaan esimerkiksi vuoteen 2000 mennessä” (Opetusministeriö 1970a, 20).

Peruskoulun ensimmäisen opetussuunnitelman perusteiden yksi erityinen aihekokonaisuus on "Joukkotiedotus" (Opetusministeriö 1970a, 36). Joukkotiedotusvälineillä katsotaan olevan koulun, kirkon, kodin ja järjestöjen lisäksi vastuu yhteiskunnan kasvatustehtävästä lasten viettäessä entistä enemmän aikaa joukkotiedotusvälineiden parissa (Opetusministeriö 1970a, 34, 36, 70). Ne halutaan valjastaa pedagogisiin tarkoituksiin, mutta samaan aikaan joukkotiedotuskasvatuksessa korostetaan pyrkimystä kriittisyyteen joukkotiedotusvälineiden tarjoamaa tietoa kohtaan (Opetusministeriö 1970a, 256). Tarkennettaessa varsinaisiin joukkotiedotusvälineisiin sanomalehti mainitaan usein itseoikeutettuna median edustajana. Television ja radion lisäksi modernia laitekantaa ja uusimuotoista suhtautumista opiskeluun edustavat erilaiset piirtoheittimen kaltaiset "opetuskoneet" ja toisaalta oppimispelit (Opetusministeriö 1970a, 34, 112-113).

Vuoden 1970 opetussuunnitelman perusteiden ensimmäisessä osassa on omistettu kokonainen pääluku opetusvälineille ja -materiaaleille, joista annetaan varsin yksityiskohtaisia ohjeistuksia. Toisaalta laitteiden käyttöä myös problematisoidaan ja varoitellaan niiden liiallisesta ja itsetarkoituksellisesta käytöstä. Silti tekstistä välittyy enemmän huoli siitä, että käytetäänkö kouluissa riittävästi moderneja opetusvälineitä ja -materiaaleja. Siksi ehdotetaan perustettavan erityisiä kuntakohtaisia opetusvälinekeskuksia, jotka toimisivat peruskoulua palvelevana resurssikeskuksena (Opetusministeriö 1970a, 116).

Tarkasteltaessa koulun varsinaisia oppiaineiden opetussuunnitelmia eli opetussuunnitelman toista osaa on havaittavissa, kuinka ensimmäisen osan suhteellisen voimakas usko opetusteknologiaan ilmenee myös oppiaineissa. Esimerkiksi äidinkielessä toivotaan keskusteltavan TV- ja radio-ohjelmista (Opetusministeriö 1970b, 32). Kielten opiskelussa toivotaan käytettävän teknisiä apuvälineitä kuten nauhoittimia, levysoittimia ja radiota (Opetusministeriö 1970b, 121). Itse asiassa lähes jokaisessa oppiaineessa - alkaen matematiikasta ja päätyen maatilatalouteen - viitataan johonkin tieto- ja viestintätekniseen toimintoon. Lisäksi mainitaan tuolloista modernia opetusteknologiaa edustaneet kuultokuvanheittimet ja episkoopit unohtamatta TV- ja radio-ohjelmia sekä sanomalehtiä. 


\section{Peruskoulun opetussuunnitelman perusteet 1985}

Peruskoulu oli 1980-luvulla vähitellen vakiintumassa osaksi suomalaista yhteiskuntaa. Ensimmäisestä opetussuunnitelmasta vastasi opetusministeriö, kun taas vuoden 1985 ja sen jälkeen ilmestyneistä opetussuunnitelman perusteista ovat vastanneet Kouluhallitus ja sittemmin sen seuraaja Opetushallitus (Rokka 2011, 23; Vitikka 2009, 63). Peruskoulun opetussuunnitelman perusteet 1985 (Kouluhallitus 1985) on ensimmäinen nimenomaan kuntakohtaiseen käyttöön tarkoitettu suunnitelma opetuksen järjestämiseksi: "Opetussuunnitelman tulee antaa riittävän selkeät perusteet opetukselle, mutta se ei saa kuitenkaan rajoittaa opetuksen monipuolista toteuttamista" (Kouluhallitus 1985, 19). Keskusjohtoisuuden vähentämisen lisäksi haluttiin korostaa opetussuunnitelman luonnetta elävänä asiakirjana, jota tuli kehittää koko ajan paikalliset olot huomioiden. Kasvaneesta alueellisesta päätösvallasta huolimatta 1980-luvun peruskoulua voidaan pitää edelleen valtiojohtoisena ja normiperustaisesti hallittuna organisaationa (Ahonen 2004, 160; Kouluhallitus 1985, 7; Rokka 2006, 23-26; Simola 1995; 43-44, 278; Varjo 2007).

Edellisen, vuoden 1970 opetussuunnitelman perusteiden toistuvat viittaukset opetusteknologiaan ovat vuonna 1985 jääneet pois yleisestä osasta lähes kokonaan. Tosin aihekokonaisuus "Joukkotiedotus" on edelleen mukana. Teknologia ja sen tuntemus mainitaan vain kerran kohdassa, jossa korostetaan yhteiskunnan, työelämän ja ammatinvalinnan tuntemusta. Valinnaisia aineita lukuun ottamatta vain matematiikassa otetaan huomioon tietojenkäsittelyn nopea kehitys (Kouluhallitus 1985, 147-150). Muiden oppiaineiden yhteydessä (kuten historia ja yhteiskuntaoppi sekä biologia ja maantieto) mainitaan vain joukkotiedotus, joukkotiedotusvälineet tai joukkotiedotuskasvatus.

Vasta peruskoulun lisäopetuksen oppimäärissä eli niin sanottujen valinnaisaineiden yhteydessä mainitaan tietotekniikka. Se mainitaan ensimmäisen kerran kaupallisissa aineissa. Valinnaiseen oppimäärään lukeutuva tietotekniikka sisältää luonnollisesti runsaimmin viittauksia tieto- ja viestintätekniikkaan. Yleistavoitteeksi määritellään se, että oppilas ymmärtää tietotekniikan merkityksen yhteiskunnassa ja huomaa omat "mahdollisuutensa ja rajoituksensa tietoyhteiskunnan vaatimissa valmiuksissa" (Kouluhallitus 1985, 288). Tietoyhteiskunta mainitaan nyt siis eksplisiittisesti. Muutama riviä myöhemmin asennekasvatuksen tehtäväksi määrittyy se, että "oppilas ei pelkää eikä kunnioita liikaa tietotekniikkaa ja tietokoneita" (Kouluhallitus 1985, 288). Kommentti voidaan lukea huoleksi tieto- ja viestintätekniikan mahdollisista negatiivisista seuraamuksista.

\section{Peruskoulun opetussuunnitelman perusteet 1994}

Valtionhallinnon uudistamisprojektin mukaisesti opetussuunnitelmatyötä oli tuotu lähemmäksi paikallistasoa jo edellisen opetussuunnitelman perusteiden yhteydessä. Vasta nyt opetussuunnitelmatyö mahdollisti todelliset koulukohtaiset ratkaisut. Lisäksi opettajat haluttiin sitouttaa osaksi koulun kehittämistä ja uudistamista, ja viimeistään tässä vaiheessa suomalainen opettaja saavutti nykyisen tunnustetun itsenäisen asemansa. (Rokka 2011, 2631; Simola 2005; Varjo 2007.)

Opetushallituksen pääjohtaja Vilho Hirvi ja ylijohtaja Aslak Lindström toteavat Opetussuunnitelman perusteiden ensimmäisillä sivuilla, että käsillä olevat perusteet "on laadittu prosessina laajaa sidosryhmätyötä tehden" (Opetushallitus 1994). Edellisistä perusteista poiketen 1994 perusteet kävivät lausuntokierroksilla muun muassa erilaisissa järjestöissä. Mielipiteitä haluttiin myös tutkijoilta ja elinkeinoelämältä. Ulkopuolisten osaajien hyödyntäminen opetussuunnitelmien laatimisessa kertoo osaltaan uudesta toimintakulttuurista, jos- 
sa opetussuunnitelmien uudistusprosessiin haluttiin sitouttaa tahoja, joilla katsottiin olevan perusteltuja näkemyksiä peruskoulutuksesta (Rokka 2011, 29).

Dokumentin etusivuilla tuodaan esiin yhteiskunnan voimakas teknologinen kehittyminen, minkä katsotaan edellyttävän "kansalaisilta kykyä käyttää tekniikan sovelluksia" (Opetushallitus 1994, 11). Ensin viittaukset teknologiaan esitetään yleisellä tasolla ja puhutaan muun muassa teknologian suhteesta ympäristöön, kunnes sitten tarkennetaan tietotek niikan käyttötaitoon. Tekstissä korostetaan ATK-taitoja sinällään, mutta myös välineenä muissa koulun oppiaineissa. Tiedonhankkiminen, asiakokonaisuuksien tutkiminen ja uuden tiedon tuottaminen edustavat jo varsin modernia ja aiemmista opetussuunnitelmista poiketen eriytyneempää näkemystä. Lisäksi mainitaan myönteiset kokemukset ja onnistumisen tunne, joita ATK-laitteet voivat tarjota. (Opetushallitus 1994, 35.)

Teknologia- ja tekniikkaviittaukset liikkuvat edelleen hyvin yleisellä tasolla. Kyse on kuitenkin aikaisempaa enemmän juuri tieto- ja viestintätekniikasta ilmaisun nykyisessä merkityksessä. Tämä näkyy jo yksistään siitä, että "Joukkotiedotuksen" aihekokonaisuutena perivät "Viestintäkasvatus" ja "Tietotekniikan käyttöönotto", mikä korostaa tekniikan ja viestinnän yhteenkietoumista. Tieto- ja viestintäteknisten näkemysten konkretisoituminen opetussuunnitelman varsinaisiin sisällöllisiin tai tavoitteellisiin teksteihin on kuitenkin sangen vähäistä. Esitetyt visiot jäävät yleiselle tasolle. Lisäksi viestintäpainotuksesta huolimatta kyse näyttäisi olevan enemmän ATK-taidoista, laitteistoista, ohjelmistoista ja tekstinkäsittelyn kaltaisista elementeistä, ei siis vielä laitteita ja ohjelmia yhteen kytkevistä tietoverkoista (Opetushallitus 1994, 35).

Yksittäisten ja etenkin kaikille pakollisina kuuluvien oppiaineiden kohdalla tieto- ja viestintätekniset maininnat kuitenkin lisääntyvät edelliseen opetussuunnitelmaan nähden merkittävästi. Siten esimerkiksi äidinkielessä edellytetään, että "oppilaasta kehittyy hyvä lukija ja kirjoittaja, joka hallitsee lukemisen ja kirjoittamisen sujuvan teknisen, myös mahdollisuuksien mukaan tietoteknisen, taidon" (Opetushallitus 1994, 42). Maantieteessä puolestaan edellytetään, että oppilas "oppii hankkimaan ajankohtaista tietoa monipuolisesti, myös tiedonsiirtotekniikkaa käyttäen" (Opetushallitus 1994, 83).

Tieto- ja viestintätekniikka nähdään vuoden 1994 opetussuunnitelman perusteissa huomioon otettavana seikkana ja suoranaisena kansalaisvelvollisuutena, mutta sen ohjeistamiseen varsinaisessa koulutyössä paneudutaan hyvin summittaisesti. Näyttäisi siltä, että huomion ollessa kansainvälisen yhteisön ja globalisoituvan talouselämän kysymyksissä jäävät tarkemmat pohdinnat luokkahuonetason työskentelystä määrittelemättä - tai ne on tarkoituksellisesti jätetty tuolloisen opetussuunnitelma-ajattelun mukaisesti paikallisesti pohdittaviksi.

\section{Perusopetuksen opetussuunnitelman perusteet 2004}

Siinä missä vuoden 1994 opetussuunnitelman perusteet korostivat koulukohtaisuutta, jää koulukohtaisuus taka-alalle Perusopetuksen opetussuunnitelman perusteissa 2004. Toisaalta tätä opetussuunnitelmaprosessia ei laadintavaiheessa altistettu edeltäjänsä tavoin laajalle lausuntokierrokselle (Rokka 2011, 7). Tieto- ja viestintätekniikassa oli kuitenkin tapahtunut paljon. Tultaessa 2000-luvulla oli Internet jo suhteellisen vakiintunut. Siten opetussuunnitelmatekstiin mahtuvat nyt myös tietoverkot:

Oppimisympäristön varustuksen tulee tukea myös oppilaan kehittymistä nykyaikaisen tietoyhteiskunnan jäseneksi ja antaa tilaisuuksia tietokoneiden ja muun mediatekniikan sekä mahdollisuuksien mukaan tietoverkkojen käyttämiseen (Opetushallitus 2004, 18). 
Jo edellisessä opetussuunnitelmassa mainittu oppimisympäristö virittyy nyt erityisesti tietoyhteiskunnan tarpeisiin. Samoin yleisen tekniikan tai teknologian sijasta korostuu ensisijaisesti tieto- ja viestintätekniikka. TVT:hen kytkeytyvä aihekokonaisuus on "Ihminen ja teknologia", jonka tarkoituksena on auttaa "oppilasta ymmärtämään ihmisen suhdetta teknologiaan ja auttaa näkemään teknologian merkitys arkielämässämme". Edellisten opetussuunnitelmien tavoin teknologiaa tulee ymmärtää. Lisäksi korostetaan vastuullisuutta ja tarvetta ymmärtää teknologiaan liittyvien päätösten mahdollisia vaikutuksia tulevaan (Opetushallitus 2004, 42.) Toinen aihekokonaisuus "Viestintä- ja mediataito" korostaa mediakriittisyyttä ja median ymmärtämistä sekä harjaantumista viestien vastaanottamiseen ja tuottamiseen. (Opetushallitus 2004, 39-40.) Kummassakin aihekokonaisuudessa mainitaan lyhyesti tietotekniset (tai viestintätekniset) laitteet ja tietoverkot (Opetushallitus 2004, 39-42).

Vaikka tieto- ja viestintätekniikka näkyykin yleisessä osassa osin piilotettuna teknologiapuheeseen, moni oppiaine vaikenee edellisten perusteiden tavoin tieto- ja viestintätekniikasta. Yksittäisistä oppiaineista äidinkieli ja kirjallisuus, kielet, kuvataide ja käsityö mainitsevat usein tieto- ja viestintätekniikkaan liittyviä seikkoja, kuten viestintävalmiudet, tietotekniikan, tekstinkäsittelyohjelman, sähköiset lähteet, digitaaliset tekstit ja tiedonhaut verkosta. Huomio kiinnittyy siihen, kuinka humanistisissa kieliaineissa ja taito- ja taideaineissa ovat tieto- ja viestintätekniset maininnat hyvin edustettuna, kun taas matemaattis-luonnontieteellisissä aineissa tieto- ja viestintätekniset maininnat ovat suhteellisen vähäisiä. Seuraavat aineet eivät puolestaan ota minkäänlaista kantaa tieto- ja viestintätekniikkaan: ympäristö- ja luonnontieto, terveystieto, uskonto ja elämänkatsomustieto, historia ja yhteiskuntaoppi, musiikki, liikunta ja kotitalous.

\section{Perusopetuksen opetussuunnitelman perusteet 2014}

Kaikki suomalaisen peruskoulun opetussuunnitelman perusteet rakentuvat selkeästi akateemisten oppiaineiden pohjalle (Schiro 2013, 15-56). Viimeisin, voimassa oleva Perusopetuksen opetussuunnitelman perusteet 2014 tuo kuitenkin perinteisen ainejakoisen opetussuunnitelman tilalle mahdollisuuden toteuttaa opetusta myös eheytettynä (Opetushallitus 2014 , 8). Samoin paikallisuus viedään nyt aivan uudelle tasolle: paikallisuus voi merkitä kunkin koulun omaa tai toisten koulujen kanssa yhteistä suunnitelmaa tai jotain "muuta ratkaisua" (Opetushallitus 2014, 10).

Vasta viimeisimmissä, käytössä olevissa opetussuunnitelmien perusteissa tieto- ja viestintätekninen puhe näyttäytyy sellaisena, joka nyky-yhteiskunnassa elävän on helppo tunnistaa:

Arvokasvatuksen merkitys korostuu maailmassa, jossa monimediainen tiedonvälitys, globaalit tietoverkot, sosiaalinen media ja vertaissuhteet muokkaavat lasten ja nuorten arvomaailmaa (Opetushallitus 2014, 13).

Teknologiaan liitetään arvoperusta, joka korostaa vastuuta teknologisista valinnoista. Samoin tulevaisuuspuhe tarkentuu ylisukupolvisuuteen ja jättämämme perinnön luonteeseen sekä kestävään kehitykseen (Opetushallitus 2014, 14, 21). Ajattelu tiivistyy seitsemään laaja-alaiseen osaamisalueeseen, joilla tavoitellaan oppiainerajat ylittävää ja yhdistävää osaamista. Niiden yhteisenä tarkoituksena on tukea "ihmisenä kasvamista sekä edistää demokraattisen yhteiskunnan jäsenyyden ja kestävän elämäntavan edellyttämää osaamista" (Opetushallitus 2014, 18). Edellisten opetussuunnitelmien tavoin vuoden 2014 opetussuunnitelman perusteet peräänkuuluttavat perustietoa teknologiasta ja sen vaikutuksista. Järkeviä teknologisia valintoja ja vastuullisuutta korostetaan unohtamatta 
eettisiä kysymyksiä (Opetushallitus 2014, 20-21). Teknologian katsotaan olevan kiistaton osa nyky-yhteiskuntaa, ja meidän tehtävämme on suhtautua siihen vastuullisesti.

Erityisen mielenkiinnon kohteena on "Tieto- ja viestintäteknologinen osaaminen" eli laaja-alainen osaamisalue L5. Tieto- ja viestintäteknologisen osaamisen kehittämisen tulee toteutua neljällä pääalueella. Näistä ensimmäinen on ymmärrystä ja tietoa koskeva, toinen on vastuullisuus ja turvallisuus. Kolmas näkökulma liittyy tiedonhallintaan ja tutkivaan työskentelyyn neljännen viitatessa vuorovaikutukseen ja verkostoitumiseen. (Opetushallitus 2014,21 .) Tieto- ja viestintätekniikkaa koskevissa määrittelyissä liikutaan aivan erilaisella tarkkuuden tasolla kuin aikaisemmissa opetussuunnitelmien perusteissa. Toinen tietoja viestintätekniikkaan viittava laaja-alainen osaamisalue L4 on nimetty "Monilukutaito", jonka avulla korostetaan tekstien tulkitsemista, tuottamista ja arvottamista monimuotoisessa viestintämaailmassa osana oman identiteetin rakentamista (Opetushallitus 2014, 20-21).

Viimeisin, voimassa oleva opetussuunnitelma pohjautuu kompetenssipohjaiselle opetussuunnitelmamallille, joka on eräällä tapaa vastakkainen perinteiselle oppiainepohjaiselle mallille. Toivotut suoritukset määritellään kompetenssipohjaisessa mallissa käyttäytymistai oppimistavoitteiksi ja sisältöinä voivat olla perinteisten oppiaineihin pohjautuvien sisältöjen lisäksi tai niiden sijaan myös oppimiskokemukset. (Vitikka 2009, 86-87.)

Opetussuunnitelman perusteet 2014 esittelee yksityiskohtaisesti jokaisen oppiaineen kohdalla taulukoita, joissa on kuvattu opetuksen tavoitteet ja niihin liittyvät sisältöalueet. Edelleen nämä tavoitteet ja sisältöalueet liittyvät johonkin tai joihinkin seitsemästä esitellystä laaja-alaisesta osaamisalueesta. Tarkastelun kohteena olevat L5 "Tieto- ja viestintäteknologinen osaaminen" ja L4 "Monilukutaito" kytkeytyvät liikuntaa lukuun ottamatta kaikkien peruskoulun oppiaineiden tavoitteisiin ja sisältöalueisiin tuottaen lopulta erittäin yksityiskohtaisen ja oppiaineiden sisältöihin tunkeutuvan matriisin. Vaikka yleisessä osassa tuodaan esille aktiivista asennetta tieto- ja viestintätekniikkaa kohtaan, oppiaineiden yksittäiset tieto- ja viestintätekniset kytkennät vaikuttavat usein päälleliimatuilta, kuin vastauksilta ilmeiseen ulkoiseen paineeseen esittää mahdollisimman runsaasti digitaalisuuteen tai TVT:hen liittyviä mainintoja (Pirhonen 2019). Siten esimerkiksi uskonnon opetuksessa tavoite "kannustaa oppilasta kunnioittamaan omaa ja toisen pyhää sekä käyttäytymään asianmukaisesti erilaisissa uskonnollisissa tilaisuuksissa ja tilanteissa" kytkeytyy tieto- ja viestintäteknologiseen osaamiseen (Opetushallitus 2014, 274).

\section{Tieto- ja viestintätekniikkaan liittyvien merkitysten muuttuminen}

Olen koonnut taulukkoon 1 opetussuunnitelman perusteista tekemäni tiivistetyt havainnot. Vasemmasta sarakkeesta selviävät kunkin opetussuunnitelman perusteen tieto- ja viestintätekniikkaan liittyvät aihekokonaisuudet. Martti Hellström (2015) on tarkastellut peruskoulun aihekokonaisuuksia ja niiden muuttumista. Laaja-alainen osaamisalue L5 (Tieto- ja viestintäteknologinen osaaminen) on tulkittavissa suoraksi jatkoksi vuosien 1970 ja 1985 opetussuunnitelmien "Joukkotiedotukselle" ja vuoden 2004 opetussuunnitelman perusteiden "Viestintä- ja mediataidolle" sekä "Ihminen ja teknologia" -aihepiirille. Vaikka pohjimmiltaan on kyse samansisältöisistä aihealueista, ovat 2014 perusteiden aihealueet kompetenssi- eli taitopohjaisia. Aikaisemmissa aihealueissa taas korostuivat joukkotiedotuksen kaltaiset temaattisesti painottuneet alueet.

Toiseksi taulukosta 1 ilmenevät tulkitsemani keskeiset asiasanat, jotka heijastelevat kunkin opetussuunnitelmatekstin ajankohdan terminologisia painotuksia. Tämä on puolestaan toiminut esiaskeleena kolmannelle sarakkeelle, jossa on tulkittu kunkin opetussuunnitelman keskeisiä ideoita. Lopuksi taulukon 1 oikeanpuolimmaisesta sarakkeesta ilmenee 
jokaiselle opetussuunnitelmalle antamani nimi, joka pyrkii tiivistämään edeltävien vaakasuorien ruutujen havainnot kuvaamalla kunkin opetussuunnitelman henkeä ja koulun itsestään välittämää kuvaa tieto- ja viestintäteknisestä näkökulmasta katsottuna.

\begin{tabular}{|c|c|c|c|}
\hline Aihekokonaisuus & Keskeiset asiasanat & Keskeiset ideat & OPS \\
\hline Joukkotiedotus & $\begin{array}{l}\text { Opetusteknologia, } \\
\text { joukkotiedotus } \\
\text { (kasvatus), av-välineet, } \\
\text { opetusvälinekeskukset }\end{array}$ & $\begin{array}{l}\text { OPS tulevaisuuteen } \\
\text { katsovana: TVT } \\
\text { lupaavana ja käyttöön } \\
\text { kannustavana, teknologia } \\
\text { kuuluu kaikille, } \\
\text { teknologian vaaroista } \\
\text { varoittava }\end{array}$ & $\begin{array}{l}1970- \\
\text { teknologiseen } \\
\text { tulevaisuuteen } \\
\text { kurkottava } \\
\text { koulu }\end{array}$ \\
\hline Joukkotiedotus & $\begin{array}{l}\text { Tietotekniikka, } \\
\text { tietokone } \\
\text { joukkotiedotus(kasvatu } \\
\text { s), ATK, } \\
\text { tietoyhteiskunta }\end{array}$ & $\begin{array}{l}\text { TVT vetäytyvänä ja } \\
\text { satunnaisena }\end{array}$ & $\begin{array}{l}1985- \\
\text { perusasioihin } \\
\text { keskittyvä } \\
\text { koulu }\end{array}$ \\
\hline $\begin{array}{l}\text { Viestintäkasvatus, } \\
\text { tietotekniikan } \\
\text { käyttöönotto }\end{array}$ & $\begin{array}{l}\text { Tietotekniikka, ATK, } \\
\text { uusi teknologia, } \\
\text { viestintäkasvatus, } \\
\text { tiedonhankinta, } \\
\text { oppimisympäristö }\end{array}$ & $\begin{array}{l}\text { TVT:n kytkeytyminen } \\
\text { kansainvälistymiseen, } \\
\text { kilpailuun ja } \\
\text { yksilöllisyyteen, TVT } \\
\text { jokaisen kansalaisen asia, } \\
\text { keskusjohtokielteisyys }\end{array}$ & $\begin{array}{l}1994- \\
\text { yksilöllistyvä, } \\
\text { kilpaileva ja } \\
\text { avoin koulu }\end{array}$ \\
\hline $\begin{array}{l}\text { Viestintä- ja } \\
\text { mediataito, } \\
\text { Ihminen ja } \\
\text { teknologia }\end{array}$ & $\begin{array}{l}\text { Tietoverkot, } \\
\text { tietoyhteiskunta, } \\
\text { tiedonhaku, digitaaliset } \\
\text { materiaalit, sähköiset } \\
\text { lähteet, verkottunut } \\
\text { oppimisympäristö } \\
\end{array}$ & $\begin{array}{l}\text { Teknologia tarkentuu } \\
\text { TVT:aan; TVT } \\
\text { velvoittavana ja } \\
\text { verkottuvana }\end{array}$ & $\begin{array}{l}2004- \\
\text { verkottuva } \\
\text { koulu }\end{array}$ \\
\hline $\begin{array}{l}\text { Tieto- ja } \\
\text { viestintäteknologin } \\
\text { en osaaminen, } \\
\text { Monilukutaito }\end{array}$ & $\begin{array}{l}\text { Monimediaisuus, } \\
\text { monilukutaito, } \\
\text { digitaalisuus, }\end{array}$ & $\begin{array}{l}\text { TVT kaiken läpäisevänä } \\
\text { ja tarkentuvana, kestävä } \\
\text { kehitys, } \\
\text { oppiainejakoisuuden } \\
\text { tilalle eheyttämistä, } \\
\text { kompetenssit }\end{array}$ & $\begin{array}{l}2014- \\
\text { sisällöistä } \\
\text { digitaitoihin }\end{array}$ \\
\hline
\end{tabular}

Taulukko 1. Tieto- ja viestintätekniikka peruskoulukauden opetussuunnitelmissa 19702014.

Vuoden 1970 opetussuunnitelma heijastelee teknologiseen tulevaisuuteen katsovaa koulua. Ensimmäisistä peruskoulun tarpeisiin suunnitelluista opetussuunnitelmadokumenteista välittyy usko teknistyvään laitekantaan ja oppikirjan ulkopuoliseen sisältöön. Taustalla voidaan nähdä maatalousvaltaisen Suomen muuntuminen teknologialähtöiseksi moderniksi länsimaiseksi yhteiskunnaksi, jossa haluttiin huolehtia myös tasa-arvon toteutumisesta koulutuskysymyksissä. Teknologiausko näyttäisi heijastelevan tuolloin vallalla ollutta näkemystä peruskoulun kyvystä voittaa perinteiset koulun ongelmat, kuten oppimiseen ja oppilaiden käyttäytymiseen liittyvät haasteet (Alasuutari 1996; Lahdes 1980, esipuhe; Rinne 1984). 
Ensimmäinen peruskoulun opetussuunnitelma ottaa selvän kannan opetusteknologian systemaattisen käyttöön myös perusopetuksessa. Peruskoulun idean mukaisesti tieto- ja viestintätekniikka nähdään kaikille kuuluvaksi, ja tästä peruskoulun tuli huolehtia. Ensimmäinen peruskoulun opetussuunnitelma esittää varsin selkeän kannanoton, jossa huomioidaan teollistuminen, elintason nousu ja urbanisoituva yhteiskunta, ja josta tulee ohjenuora, jota seuraavat opetussuunnitelman perusteet yksi toisensa jälkeen myötäilevät: "Teknistyvässä maailmassa ihmiskunnan on muututtava demokraattisemmaksi ja inhimillisemmäksi" (Opetusministeriö 1970a, 23-25). Toisaalta varoitellaan, ettei modernien audiovisuaalisten välineiden käyttö saisi johtaa epäolennaisuuksiin ja muistutetaan, että opetusteknologian on ensisijaisesti palveltava tehokasta oppimista. Vaikka ensimmäisen analysoidun opetussuunnitelman perusteet kurkottavat kaukaiseen tulevaisuuteen, jättää se silti monia asioita avoimeksi ja ratkaistavaksi väistäen näin deterministiset tulevaisuusvisiot.

Näyttää siltä, että tieto- ja viestintätekniikkaan liittyvät, vuoden 1970 opetussuunnitelman yhteydessä mainitut mittavat teknologiset odotukset olisi 1980-luvulle tultaessa haudattu lähes kokonaan. Koulu ikään kuin keskittyi kasvatuksen peruskysymyksiin ja vältteli teknologisten visioiden esittämistä. Syitä tähän voidaan pohtia. Ilmeisesti huomattiin, että peruskoulussa oli ratkaistavana monia käytännöllisiä ja edellisestä koulutusjärjestelmästä periytyviä kysymyksiä, joilla ei ollut suoraa yhteyttä tieto- ja viestintätekniikkaan. Siirtyminen rinnakkaiskoulusta kaikille yhteiseen peruskouluun oli merkittävä muutos, joka ei miellyttänyt kaikkia, osa opettajista mukaan lukien. Opettajakunta on myös saattanut suhtautua epäluuloisesti tieto- ja viestintätekniikan tarjoamiin pedagogisiin mahdollisuuksiin. Lisäksi kunnissa lienee ollut kovin erilaisia haluja ja resursseja tarjota moderneja opetusvälineitä ja -materiaaleja, mikä lienee havaittu myös opetussuunnitelmien perusteiden laatijoiden keskuudessa.

Kolmas peruskoulukauden opetussuunnitelma ottaa selkeän kannan teknologiaan ja tarkentaa erityisesti tieto- ja viestintätekniikkaan, josta on nyt tullut jokaisen kansalaisen asia. Vuoden 1994 opetussuunnitelman perusteissa tapahtuu edellisiin opetussuunnitelmiin verraten selvä puhetavan muutos: koulu näyttäytyy yksilöllistyvänä, kilpailevana ja avoimena. Vuoden 1994 opetussuunnitelman perusteissa yhteiskunnalliset muutospaineet ja tieteellinen kehitys sekä niihin kytkeytyvä "uusi teknologia" tuodaan eksplisiittisesti esiin. Mahdollisuuksista on tultu välttämättömyyksiin. Samoin kansainvälistyminen sekä työ- ja elinkeinoelämän muutokset mainitaan. Koulun halutaan kuvastavan palvelukyvykkyyttä ja mahdollisuutta vastata yksilöllisiin koulutustarpeisiin, ja alati kehittyvän teknologian tulee olla osa koululaitoksen vastausta esitettyihin haasteisiin. Tieto- ja viestintätekniikka kytkeytyy kansainvälisyyteen, kilpailuhenkisyyteen ja näihin liittyvään palvelualttiuteen. (Alasuutari 1996; Opetushallitus 1994, 8; Rokka 2011, 29.)

Siinä missä vuoden 1970 opetussuunnitelman perusteissa (Opetusministeriö 1970a) halutaan huolehtia peruskoulun kyvystä tarjota kaikille oppilailleen mahdollisuuksia viimeisimpään tieto-ja viestintätekniikkaan, siirtyy vastuu peruskoulukauden kolmannessa opetussuunnitelmassa 1994 yhä enemmän oppijoille itselleen. On kuitenkin huomattava se, että kyse ei ole yksipuolisesta tekniikan vastaanottamisesta tai kuluttamisesta, vaan tekniikan ymmärtämiseen katsotaan kuuluvan myös vaikuttaminen teknologisen kehityksen suuntaan. Huolimatta 1990-luvun teknologiamyönteisestä Suomi tietoyhteiskunnaksi -projektista (Valtiovarainministeriö, 1995a; 1995b) ja vuoden 1994 opetussuunnitelman perusteiden yleisen osan teknologiatietoisuudesta, jää tieto- ja viestintätekniikan rooli kuitenkin varsin vähäiseksi. On mahdollista, että vuoden 1994 opetussuunnitelman mahduttaminen suhteellisen vähään tilaan on osaltaan verottanut mahdollisuuksia tarkentaa tieto- ja viestintätekniikkaan liittyvä oletuksia ainakin yksittäisten oppiaineiden osalta. 
Tietoyhteiskunta mainitaan jo vuoden 1985 opetussuunnitelman perusteissa, mutta vasta vuoden 2004 opetussuunnitelman perusteiden voidaan katsoa rakentuvan tietoyhteiskunnan varaan. Siinä missä vuoden 1994 opetussuunnitelman perusteissa tieto- ja viestintätekniset huomautukset liittyvät ensisijaisesti tieto- ja viestintäteknisiin laitteisiin tai ohjelmistoihin, lisääntyvät nyt viittaukset mediaan, viestintään ja tietoverkkoihin. Internet yhdisti viimeistään 2000-luvulle tultaessa tietoverkkojen ulkopuoliset ja yksittäiset tietotekniset laitteet luoden aivan uusia mahdollisuuksia (Opetushallitus 2004, 39-40). Edellisen opetussuunnitelman aikana tapahtunut koulun avautuminen konkretisoituu uuden vuosituhannen opetussuunnitelmassa koulun mahdollisuutena kytkeytyä tietoverkkoihin.

Viimeisimmät opetussuunnitelman perusteet kuvaa koulua, jossa sisältöjen ohella korostuvat taidot ja etenkin digitaidot (Pirhonen 2019). Opetus- ja kulttuuriministeriö (2015) toteaakin koulutuksen kärkihankkeisiin (ks. esim. Valtioneuvosto 2018) viitaten, että "siirtyminen liitutauluajasta digiaikaan on iso urakka koulullemme". Viittauksen liitutauluaikaan voi tulkita osoitukseksi siitä, että ensimmäisistä vuoden 1970 perusteista huokuvat tulevaisuusvisiot eivät ole vieläkään toteutuneet. Lisääntyneestä tieto- ja viestintätek nisestä puheesta huolimatta viimeisimmät opetussuunnitelman perusteet ottavat siis kiinni siitä menneisyyden pyrstöstä, jonka jo vuoden 1970 perusteet halusivat aikanaan katkaista. Lisäksi oppiainejakoisuuden tilalle tai oheen tarjotaan laaja-alaista osaamista, mihin tietoja viestintätekniikka usein kytkeytyy. Laaja-alaisuuden yhteydessä nimittäin mainitaan usein 21. vuosisadan taidot, monialaisuus ja ilmiöoppimiminen, joiden luvataan tarjoavan oppiaineet ylittävää, toisinaan myös niitä kyseenalaistavaa lähestymistapaa (Lonka 2018, 173; Schiro 2013, 99-150; Vahtivuori-Hänninen ym. 2014).

\section{Yhteenveto}

Vuoden 1970 opetussuunnitelman perusteet muodostavat varsin visionäärisen näkemyksen tuolloisen ja myös tulevan tieto- ja viestintätekniikan merkityksestä peruskoulussa, ja samaan aikaan ne korostavat teknologian kuulumista kaikille. Vuoden 1985 opetussuunnitelma puolestaan eroaa suuresti edeltäjästään lähes vaikenemalla tieto- ja viestintätekniikasta. Voi vain arvailla, johtuiko tämä edellisten perusteiden teknologisesta ylioptimismista vai tilanteesta, jossa oltiin havahduttu vasta perustetun peruskoulun muihin haasteisiin. Toisaalta varsinainen poikkeama saattaakin olla vuoden 1970 perusteet innovatiivisuudessaan.

Vuoden 1994 opetussuunnitelman perusteet esittelevät selvästi uudenlaisia yksilöllisyyteen, kilpailullisuuteen ja kansainvälistymiseen liittyviä seikkoja. Vuoden 2004 perusteet puolestaan mainitsevat uutena asiana tietoverkot. Viidennet eli viimeisimmät perusteet korostavat laaja-alaista osaamista ja kompetenssipohjaisuutta kytkettynä tieto- ja viestintätekniikkaan. Viimeistään tässä vaiheessa oppiaineisiin kytketyt satunnaiset tieto- ja viestintätekniset maininnat vaihtuvat systemaattiseen, kaikkialle ulottuvien mainintojen verkostoon. Yhteys tieto- ja viestintätekniikkaan tuntuu kuitenkin toisinaan satunnaiselta tai perustelemattomalta.

Teknologia on mukana kaikissa tarkastelluissa opetussuunnitelman perusteissa ja niiden kaikkien asenne teknologiaan on myönteinen (Rokka 2011, 253). Tultaessa kohti nykyaikaa teknologia viittaa entistä enemmän juuri tieto-ja viestintätekniikkaan. Yhdessäkään esitellyistä viidestä opetussuunnitelman perustedokumentissa ei kuitenkaan propagoida teknologian eikä tieto- ja viestintätekniikan puolesta, vaan ne kaikki pikemmin toteavat tieto- ja viestintätekniikan merkityksen omana aikanaan länsimäiseen yhteiskuntaan elimellisesti kuuluvana seikkana kullekin aikakaudelle ominaisella tavalla. Uuden vuosituhannen myötä rakentuvat tietoverkot korostavat teknologian merkitystä, mutta samalla myös vastuulli- 
suutta. Siinä missä alkuvaiheen kriittinen mediankäyttäjä nähdään vastaanottajana, korostuvat nykypäivään tultaessa näkemykset mediantuottajasta, mikä heijastelee median tuottajavastaanottaja-asetelman muuttumista. Opetussuunnitelmista ei siis välity sellaista retorista digioptimismia tai uskoa yksipuoliseen tieto- ja viestintätekniikan siunauksellisuuteen, joka oli havaittavissa johdannon asiantuntijanäkemyksissä.

Kuten analyysini osoittaa, ensimmäinen peruskoulun opetussuunnitelman perustedokumentti (1970) luo tieto- ja viestintätekniikan osalta peruslähtökohdan, mille myös myöhemmät opetussuunnitelman perusteet rakentuvat. Vaikka teknologia ja siihen viittaavat termit vähitellen muuttuvat, kaikissa analysoimissani opetussuunnitelman perusteissa korostuu sosiaalisissa tilanteissa rakentuva ja vastuullisuutta korostava näkemys tieto- ja viestintätekniikasta sekä aktiivinen, usein myös kriittinen suhtautuminen teknologiaan.

TVT:n käyttöön liittyviä normatiivisia odotuksia tulee esille vain yksittäistapauksissa ja melko harvoin, koskivatpa ne sitten tieto- ja viestintätekniikkaan liittyviä negatiivisia tai positiivisia merkityksiä. Toisaalta tieto- ja viestintätekniikan rinnastaminen muihin teemoihin, kuten vastuulliseen kuluttamiseen, saattaisi nostaa esiin myös ristiriitaisia seikkoja. (Oliver 2011; Pirhonen 2019; Selwyn 2010; 2011.)

Tutkimuksessani en ole ottanut kantaa opetussuunnitelmien laadintaprosessiin enkä niiden varsinaiseen käyttöön opetustilanteissa. Olisi kiinnostavaa tutkia opetussuunnitelmien perusteiden laatimisvaiheessa esitettyjä tieto- ja viestintätekniikkaan liittyviä argumentteja ja niiden päätymistä lopullisiin perusteisiin. Voi vain pohtia, kuinka paljon esimerkiksi tämän artikkelin kirjoitushetkellä vallinneet tuoreet kokemukset tieto- ja viestintätekniikan käytöstä koronaepidemian yhteydessä vaikuttavat tuleviin opetussuunnitelmien perusteisiin. Erityisen kiinnostavan jatkotutkimuskohteen muodostavat opetussuunnitelmien käytännön toteutumisesta vastaavat suomalaiset opettajat, jotka ovat perinteisesti hyödyntäneet tieto- ja viestintätekniikkaa eurooppalaisia kollegoitaan vähemmän laitekannan edustaessa kuitenkin kärkipäätä (ks. esim. European Commission 2012). Myös opettajien ammattijärjestö on esittänyt huolensa digitalisaation hitaasta etenemisestä kouluissa (OAJ 2016). Tuoreen selvityksen (Tanhua-Piiroinen ym. 2019) mukaan suomalaisten opettajien tieto- ja viestintätekninen osaaminen on kuitenkin parantunut ja asenteet ovat muuttuneet myönteisemmiksi, minkä voi olettaa heijastelevan suhteellisen runsasta resurssointia ja peruskoulun uusien oppimisympäristöjen sekä digitaalisuuden edistämiseen liittyvää kärkihankestatusta (Valtioneuvosto 2018).

Opettajakunnalla on erittäin merkittävä rooli tieto- ja viestintätekniikan opetuskäytössä sekä viime kädessä erilaisten tieto- ja viestintätekniikkaan liittyvien merkitysten tunnistamisessa ja konkretisoimisessa. Tämän analyysin perusteella voidaan todeta, että opetussuunnitelman perusteet ovat luoneet koko peruskoulukauden ajan ilmeisen hyvät puitteet pohtia tieto- ja viestintätekniikan merkityksiä. Lopullisiin opetustilanteessa tehtyihin tulkintoihin vaikuttavat opettajien henkilökohtaisten intressien ja opetussuunnitelman ohella monet muut seikat, kuten julkinen keskustelu ja mahdolliset paikalliset digistrategiat.

\section{Lähteet}

Opetussuunnitelmien perusteet ilmestymisjärjestyksessä

Opetusministeriö 1970a. Peruskoulun opetussuunnitelmakomitean mietintö I: Opetussuunnitelman perusteet. Komiteanmietintö 1970: A 4. Helsinki: Opetusministeriö.

Opetusministeriö 1970b. Peruskoulun opetussuunnitelmakomitean mietintö II: Oppiaineiden opetussuunnitelmat. Komiteanmietintö 1970: A 5. Helsinki: Opetusministeriö. 
Kouluhallitus 1985. Peruskoulun opetussuunnitelman perusteet 1985. Helsinki: Valtion painatuskeskus.

Opetushallitus 1994. Peruskoulun opetussuunnitelman perusteet 1994. Helsinki: Opetushallitus.

Opetushallitus 2004. Perusopetuksen opetussuunnitelman perusteet 2004. Helsinki: Opetushallitus.

Opetushallitus 2014. Perusopetuksen opetussuunnitelman perusteet 2014. Helsinki: Opetushallitus.

\section{Muut lähteet}

Elinkeinoelämän keskusliitto 2011. Oivallus-loppuraportti [www-lähde]. < $\underline{\text { https://ek.fi/ }}$ wp-content/uploads/Oivallus loppuraportti.pdf $>$ (Luettu 16.4.2020).

Harinen, Päivi, Laitio, Tommi, Niemivirta, Markku, Nurmi, Jari-Erik \& Salmela-Aro, Katariina 2015. Oppimismotivaatio, kouluviihtyvyys ja hyvinvointi. Teoksessa Ouakrim-Soivio, Najat, Rinkinen, Aija \& Karjalainen, Tommi (toim.), Tulevaisuuden peruskoulu. Helsinki: Opetus- ja kulttuuriministeriö, 66-75 [www-lähde]. < http:// julkaisut.valtioneuvosto.fi/bitstream/handle/10024/75121/okm8.pdf? sequence $=1 \&$ isAllowed $=y>($ Luettu 16.4.2020).

Liikenne- ja viestintäministeriö 2010. Kansallinen tieto- ja viestintätekniikan opetuskäytön suunnitelma [www-lähde]. < http://julkaisut.valtioneuvosto.fi/bitstream/handle/

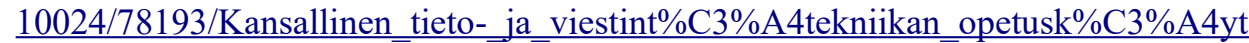
$\% \mathrm{C} 3 \% \mathrm{~B} 6 \mathrm{n}$ suunnitelma.pdf? sequence $=1 \&$ isAllowed $=\mathrm{y}>($ Luettu 16.4.2020).

Lonka Kirsti, Hietajärvi Lauri, Makkonen Juho, Sandström, Niclas \& Vaara, Lauri 2013. Tulevaisuuden opettajankoulutus - millaiseen kouluun ja miten? Teoksessa Lipponen, Päivi (toim.), Uusi oppiminen. Eduskunnan tulevaisuusvaliokunnan julkaisu 8/2013. Helsinki: Eduskunta, Tulevaisuusvaliokunta, 94-111.

OAJ 2016. Askelmerkit digiloikkaan. OAJn julkaisusarja 3:2016 [www-lähde]. < https:// www.oaj.fi/ajankohtaista/julkaisut/2016/oajn-askelmerkit-digiloikkaan/ $>$ (Luettu 16.4.2020).

Opetus- ja kulttuuriministeriö 2015. Opetus- ja kulttuuriministeri Grahn-Laasonen: Yritykset vauhdittamaan koulujen oppimisympäristöjen uudistamista [www-lähde]. < http:// minedu.fi/artikkeli/-/asset_publisher/opetus-ja-kulttuuriministeri-grahn-laasonen-yritykset-vauhdittamaan-koulujen-oppimisymparistojen-uudistamista $>$ (Luettu 16.4.2020).

Ouakrim-Soivio, Najat 2010. Läppärisukupolvi haastaa käsityksiämme oppimisesta. Teoksessa Vähähyyppä, Kaisa (toim.), Koulu 3.0. Helsinki: Opetushallitus, 40-44.

Sitra 2015. Maa jossa kaikki rakastavat oppimista. Uusi koulutus -foorumi [www-lähde]. < https://media.sitra.fi/2017/02/23070134/Maa_jossa_kaikki_rakastavat_oppimista-3.pdf $>$ (Luettu 16.4.2020).

Valtioneuvosto 2018. Ratkaisujen Suomi: Hallituksen toimintasuunnitelma 2018-2019. Valtioneuvoston julkaisusarja 27/2018 [www-lähde]. < http://julkaisut.valtioneuvosto.fi/ bitstream/handle/10024/160963/27 Hallituksen\%20toimintasuunnitelma\%2020182019.pdf?sequence=1\&isAllowed=y $>$ (Luettu 16.4.2020).

Valtiovarainministeriö 1995a. Suomi tietoyhteiskunnaksi. Strategian perustelumuistiot. Vantaa: Painatuskeskus.

Valtiovarainministeriö 1995b. Suomi tietoyhteiskunnaksi. Kansalliset linjaukset. Vantaa: Painatuskeskus. 


\section{Kirjallisuus}

Ahonen, Sirkka 2004. Yhteinen koulu: tasa-arvoa vai tasapäisyyttä? Koulutuksellinen tasa-arvo Suomessa Snellmanista tähän päivään. Tampere: Vastapaino.

Airaksinen, Timo 2003. Tekniikan suuret kertomukset. Filosofinen raportti. Helsinki: Otava.

Alasuutari, Pertti 1996. Toinen Tasavalta: Suomi 1946-1994. Tampere: Vastapaino.

Cantoni, Lorenzo \& Danowski, James A. 2015. Communication technologies: An itinerary. Teoksessa Cantoni, Lorenzo \& Danowski, James A. (toim.), Communication and Technology. Berlin/Boston, Germany: De Gruyter Mouton 2015, 3-18. https://doi.org/ $10.1515 / 9783110271355-002$

Cuban, Larry 2001. Oversold and underused: computers in the classroom. Cambridge, MA: Harvard University Press.

European Commission 2012. Survey of schools. ICT in education. Country profile: Finland [www-lähde]. < http://ec.europa.eu/information society/newsroom/image/document/ 2018-3/finland country profile 2F95B00C-C5E5-C4E9B37C237CD55B0AD0 49435.pdf $>$ (Luettu 16.4.2020).

Friesen, Norm 2008. Critical Theory. Ideology Critique and the Myths of E-learning. Ubiquity. Information anywhere. [www-lähde]. < https://ubiquity.acm.org/article.cfm? $\underline{\mathrm{id}=1386860}>($ Luettu 16.4.2020). https://doi.org/10.1145/1403922.1386860

Hawkridge, David 1990. Who needs computers in schools, and why? Computers \& Education 15 (1-3), 1-6. https://doi.org/10.1016/0360-1315(90)90121-M

Hellström, Martti 2015. OPS 2016. "Uudet aihekokonaisuudet” [www-lähde]. < http:// pedagogiikkaa.blogspot.com/2015/02/ops-2016-uudet-aihekokonaisuudet.html > (Luettu 23.5.2019).

Hoikkala, Tommi \& Kiilakoski, Tomi 2018. Digitalisaation pedagogiikka ja jatkuvan oppimisen ristiriidat. Teoksessa Hirvonen, Matti (toim.), Koulutuksen digiloikka. Miten onnistumme suomalaisten osaamisen päivittämisessä. Helsinki: Teollisuuden palkansaajat TP ry, 12-53.

Jordman, Mikko, Kiili, Kristian, Lonka, Kirsti, Schneiz, Allan \& Vauras, Marja 2015. Oppimisympäristöt ja -menetelmät. Teoksessa Ouakrim-Soivio, Najat, Rinkinen, Aija \& Karjalainen, Tommi (toim.), Tulevaisuuden peruskoulu. Helsinki: Opetus- ja kulttuuriministeriö, 76-83 [www-lähde]. < http://julkaisut.valtioneuvosto.fi/bitstream/handle/ 10024/75121/okm8.pdf?sequence $=1 \&$ isAllowed $=y>($ Luettu 16.4.2020).

Kirschner, Paul A. \& Merriënboer, Jeroen J.G. van 2013. Do Learners Really Know Best? Urban Legends in Education. Educational Psychologist 48 (3), 169-183. https://doi.org/ $10.1080 / 00461520.2013 .804395$

Klein, M.Francis, Tye, Kenneth A. \& Wright, Joyce E 1979. A Study of schooling: Curriculum. The Phi Delta Kappan 61 (4), 244-248.

Korhonen, Tiina 2017. Kodin ja koulun digitaalinen kumppanuus. Helsinki: Helsingin yliopisto.

Kumpulainen, Kristiina \& Lipponen, Lasse 2010. Koulu 3.0 - Kuinka teemme visiosta totta? Teoksessa Vähähyyppä, Kaisa (toim.), Koulu 3.0. Helsinki: Opetushallitus, 6-20.

Lahdes, Erkki 1980. Peruskoulun uusi opetusoppi. Helsinki: Otava.

Lappalainen, Antti 1985. Kamppailu peruskoulusta. Helsinki: Opettajien kustannus.

Lonka. Kirsi 2018. Phenomenal learning from Finland. Helsinki: Edita.

Marsh, Colin J. 2009. Key concepts for understanding curriculum. London: New York: Routledge. https://doi.org/10.4324/9780203870457 
McNeil, John D. 1985. Curriculum: A Comprehensive Introduction. Boston: Little, Brown.

Mertala, Pekka 2019. (Vasta)kertomuksia koulutuksen digitalisaatiosta. Kasvatus \& Aika 13 (3), 26-45. https://doi.org/10.33350/ka.76593

Meisalo, Veijo, Sutinen, Erkki \& Tarhio, Jorma 2003. Modernit oppimisympäristöt - Tietotekniikan käyttö opetuksen ja oppimisen tukena. Helsinki: Tietosanoma.

Nivala, Markus 2009. Simple answers for complex problems: Education and ICT in Finnish information society strategies. Media, Culture \& Society 31 (3), 433-448. https://doi.org/10.1177/0163443709102715

Oliver, Martin 2011. Technological determinism in educational technology research: some alternative ways of thinking about the relationship between learning and technology. Journal of Computer Assisted Learning 27 (5), 373-384. https://doi.org/10.1111/j.13652729.2011.00406.x

Passey, Don 2017. Computer science (CS) in the compulsory education curriculum: Implications for future research. Education and Information Technologies 22 (2), 421-443. https://doi.org/10.1007/s10639-016-9475-z

Pinar, William 1995. Understanding curriculum: an introduction to the study of historical and contemporary curriculum discourses. New York: Lang.

Pirhonen, Antti 2019. Mitä nykyinen koulutusteknologia-keskustelu kertoo yleissivistävän koulutuksen muutoksesta? Teoksessa Tossavainen, Timo \& Löytönen, Markku (toim.), Sähköistyvä koulu. Oppiminen ja oppimateriaalit muuttuvassa tietoympäristössä. Helsinki: Suomen tietokirjailijat ry, 33-51.

Pirhonen, Antti \& Häkkinen, Päivi 2014. Tieto- ja viestintäteknologia koulussa - uskomuksia ja niiden kyseenalaistamista. Kasvatus 45 (5), 415-417.

Player-Koro, Catarina 2016. The contemporary faith in educational technology. Tidsskrift för professionsstudier 12 (23). 98-106. https://doi.org/10.7146/tfp.v12i23.96735

Rinne, Risto 1984. Suomen oppivelvollisuuskoulun opetussuunnitelman muutokset vuosina 1916-1970: Opetussuunnitelman intentioiden ja lähtökohtien teoreettis-historiallinen tarkastelu. Turun yliopiston julkaisuja. Sarja C, 44.

Rokka, Pekka 2011. Peruskoulun ja perusopetuksen vuosien 1985, 1994 ja 2004 opetussuunnitelmien perusteet poliittisen opetussuunnitelman teksteinä. Tampere: Tampere University Press.

Ruusuvuori, Johanna, Pirjo Nikander \& Hyvärinen, Matti 2010. Haastattelun analyysin vaiheet. Teoksessa Ruusuvuori, Johanna, Nikander, Pirjo \& Hyvärinen, Matti (toim.), Haastattelun analyysi. Tampere: Vastapaino, 9-36.

Saari, Antti \& Säntti, Janne 2018. The rhetoric of the 'digital leap' in Finnish educational policy documents. European Educational Research Journal 17 (3), 442-457. https:// doi.org/10.1177\%2F1474904117721373

Salminen, Jari 2002. Alamainen sivistysprojekti, tasa-arvo ja edistys: Suomen yksityisten oppikoulujen rakenteellinen kehitys 1872-1920. Helsinki: Helsingin yliopisto.

Salo, Ulla-Maija 2015. Simsalabim, sisällönanalyysi ja koodaamisen haasteet. Teoksessa Aaltonen, Sanna \& Högbacka, Riitta (toim.), Umpikujasta oivallukseen: Refleksiivisyys empiirisessä tutkimuksessa. Tampere: Tampereen yliopistopaino, 166-190.

Schiro, Michael 2013. Curriculum theory: conflicting visions and enduring concerns. 2nd ed. Thousands Oaks, Ca: Sage Publications.

Selwyn, Neil 2009. The digital native - myth and reality. Aslib Proceedings: new information perspectives 61 (4), 364-379. https://doi.org/10.1108/00012530910973776 
Selwyn, Neil 2010. Looking beyond learning: notes towards the critical study of educational technology. Journal of Computer Assisted Learning 26 (1), 65-73. https://doi.org/ 10.1111/j.1365-2729.2009.00338.x

Selwyn, Neil 2011. Editorial: In praise of pessimism - the need for negativity in educational technology. British Journal of Educational Technology 42 (5), 713-781. https:// doi.org/10.1111/j.1467-8535.2011.01215.x

Selwyn, Neil 2016. Minding our language: Why education and technology is full of bullshit... and what might be done about it. Learning, Media \& Technology 41 (3), 437443. https://doi.org/10.1080/17439884.2015.1012523

Simola, Hannu 1995. Paljon vartijat: suomalainen kansanopettaja valtiollisessa kouludiskurssissa 1860-luvulta 1990-luvulle. Helsinki: Helsingin yliopiston opettajankoulutuslaitos.

Simola, Hannu 2005. The Finnish miracle of PISA: Historical and sociological remarks on teaching and teacher education. Comparative Education 41 (4), 455-470. https:// doi.org/10.1080/03050060500317810

Tanhua-Piiroinen, Erika, Kaarakainen, Suvi-Sadetta, Kaarakainen, Meri-Tuulia, Viteli, Jarmo, Syvänen, Antti \& Kivinen, Antero 2019. Digiajan peruskoulu. Valtioneuvoston selvitys- ja tutkimustoiminnan julkaisusarja 6/2019. Helsinki: Valtioneuvoston kanslia.

Tuomi, Jouni \& Sarajärvi, Anneli 2018. Laadullinen tutkimus ja sisällönanalyysi. Helsinki: Kustannusosakeyhtiö Tammi.

Unesco 2012. ICTs for Curriculum Change. Unesco IITE Policy Brief April 2012 [wwwlähde]. < https://iite.unesco.org/pics/publications/en/files/3214717.pdf $>$ (Luettu 16.4.2020).

Unwin, Tim 2015. ICTs and the dialectics of development. Teoksessa Cantoni, Lorenzo \& Danowski, James A. (toim.), Communication and Technology. Berlin/Boston, Germany: De Gruyter Mouton 2015, 193-214. https://doi.org/10.1515/9783110271355-012

Vahtivuori-Hänninen, Sanna, Halinen, Irmeli, Niemi, Hannele, Lavonen, Jari \& Lipponen, Lasse 2014. A new Finnish national core curriculum for basic education (2014) and technology as an integrated tool for learning. Teoksessa Lipponen, Lasse, Multisilta, Jari, Niemi, Hannele \& Vivotsou, Marianna (toim.), Finnish innovations and technologies in schools: a guide towards new ecosystems of learning. Rotterdam: Sense Publishers, 21-32. https://doi.org/10.1007/978-94-6209-749-0 2

Varjo, Janne 2007. Kilpailukykyvaltion koululainsäädännön rakentuminen. Suomen eduskunta ja 1990-luvun koulutuspoliittinen käänne. Helsinki: Helsingin yliopisto.

Vitikka, Erja 2009. Opetussuunnitelman mallin jäsennys: sisältö ja pedagogiikka kokonaisuuden rakentajina. Helsinki: Suomen kasvatustieteellinen seura.

Young, Michael \& Muller, Johan 2010. Three educational scenarios for the future: lessons from the sociology of knowledge. European Journal of Education 45 (1), 11-25. https:// doi.org/10.1111/j.1465-3435.2009.01413.x

Dos. Janne Säntti työskentelee yliopistonlehtorina Helsingin yliopiston kasvatustieteellisessä tiedekunnassa. 